\title{
Evaluation of Sludge Screening Limit for Tank Farm Low Level Waste
}

by

G. K. Georgeton

Westinghouse Savannah River Company

Savannah River Site

Aiken, South Carolina 29808

\section{DOE Contract No. DE-AC09-89SR18035}

This paper was prepared in connection with work done under the above contract number with the U.S. Department of Energy. By acceptance of this paper, the publisher and/or recipient acknowledges the U.S. Government's right to retain a nonexclusive, royalty-free license in and to any copyright covering this paper, along with the right to reproduce and to authorize others to reproduce all or part of the copyrighted paper. 


\section{DISCLAIMER}

This report was prepared as an account of work sponsored by an agency of the United States Government. Neither the United States Government nor any agency thereof. nor any of their employees. makes any warranty, express or implied. or assumes any legal liability or responsibility for the accuracy. completeaess, or usefulaess of any information. apparatus, product, or process disclosed, or represents that its use would not infringe privately owned rights. Refereace bereia to any specific commercial product, process, or service by trade name. trademark, manufacturer, or otherwise does not necessarily constitute or imply its endorsemeat, recommendation, or favoring by the United States Governmeat or any agency thereof. The views and opinions of authors expressed berein do not necessarily state or reflect those of the United States Govermment or any ageacy ihereof.

This report has been reproduced directly from the best available copy.

Available to DOE and DOE contractors from the Office of Scientific and Technical Information. P. O. Box 62, Oak Ridge. TN 37831: prices available from (615) $576-8401$.

Available to the public from the Natioan Technical Information Service. U. S. Departmeat of Commerce, S285 Port Royal Rd., Springfield. VA 22161 


\section{DISCLAIMER}

Portions of this document may be illegible in electronic image products. Images are produced from the best available original document. 
HIGH LEVEL WASTE ENGINEERING HLW ENGINEERING SUPPORT
WSRC-TR-94-0389

REVISION: 0

KEYWORDS: High Level Waste Engineering, Mercury, Alpha Contamination, Solid Low Level Waste

RETENTION: PERMANENT

CLASSIFICATION: UNCLASSIFIED

Panl D.d'intuent $8 / 11 / 94$ Classifier

EVALUATION OF SLUDGE SCREENING LIMIT FOR TANK FARM LLW (U)

BY

\author{
GUS K. GEORGETON
}

ISSUED: August 11, 1994

\section{$\longrightarrow$ \\ gs $\longrightarrow$ \\ G. K. Georgeton, Author \\ Aames Baleat Idetes}

J. R. Hester, Technical Reviewer

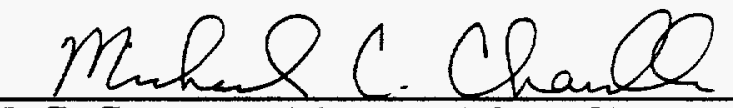

M. C. Chandler, Manager, Waste Characterization Group

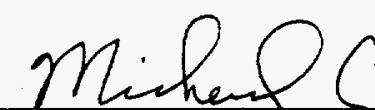

J. E. Marra, Manager, HLWE Support
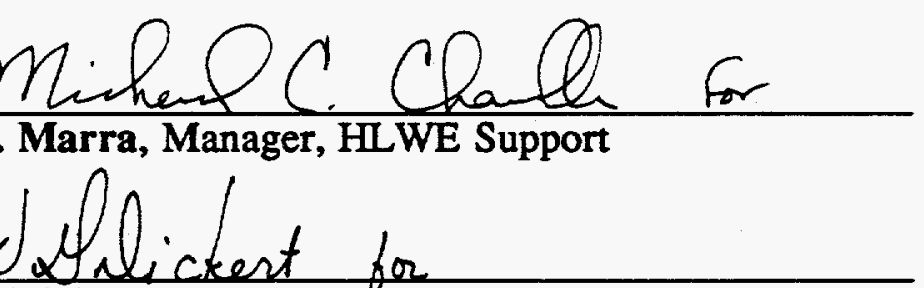

T. M. Monahon, Manager, HLWE
Date: $8 / 4 / 24$

Date: $8 / 11 / 94$

Date: $8 / 11 / 94$

Date: $8 / 11 / 94$

Date: $8 / 11 / 94$ 
WSRC-TR-94-0389

Revision 0

Page 2 of 10

\section{INTRODUCTION}

High Level Waste (HLW) generated during Separations processing in the F- and H-Canyons is transferred to the $241-\mathrm{F} / \mathrm{H}$ Tank Farms for storage in 51 underground, carbon steel tanks. The waste is an aqueous solution containing dissolved sodium salts and insoluble metal oxides/hydroxides. As the waste is collected in a receipt tank, the insoluble solids settle to form the sludge phase. The supernatant solution is decanted to an evaporator to reduce the volume. The evaporator concentrate is transferred to another waste tank and is cooled, causing the sodium salts to precipitate from solution and form the saltcake phase. Eventually, the soluble and insoluble components will be separately prepared for processing within the DWPF for final disposal.

As a result of routine and non-routine activities that are part of managing these highly radioactive wastes, secondary solid waste is generated. Low level waste (LLW) such as protective clothing, plastic sheeting, plastic huts, etc. are collected for disposal in B-25, B-12 and other waste containers. The wastes are transferred to the E-Area Vaults (EAV) for disposal, and must comply with the Waste Acceptance Criteria (WAC) for disposal of LLW. Compliance with the WAC includes manifesting the quantities of certain radioisotopes and declaring that the waste containers are not hazardous. However, solid waste is not amenable to routine smearing and analysis to determine the required information.

An alternative method has been developed and implemented to provide the necessary manifest information for solid LLW contaminated with HLW supernate [1]. The method is based on process knowledge and a limited amount of sample data. A similar method was developed to project the concentration of hazardous constituents in the leachate from the Toxic Characteristic Leach Procedure (TCLP) and is being applied to screen waste for identification of containers that are potentially hazardous [2].

A similar, but separate, evaluation for manifesting LLW contaminated with sludge is necessary due to the different radiological and hazardous characteristics. High level waste sludge has higher levels of alpha and beta contamination due to higher concentrations of actinides and fission products. Similarly, the bulk of the hazardous constituents will accumulate in the sludge, so a separate characterization for hazardous components in sludge-contaminated LLW is required. The methods to manifest containers of sludge contaminated waste are currently being developed.

In order to confidently apply the characterization of supernate contaminated waste, a method has been implemented to screen LLW to ensure that there is not enough sludge contamination to cause the radioisotope limits to be exceeded [1]. A screening parameter of $10000 \mathrm{dpm} / 100 \mathrm{~cm}^{2}$ of alpha contamination was employed and has been shown to provide the assurance that all radioisotope criteria for the EAV will be satisfied. However, additional evaluation is necessary to ensure that the sludge contamination at levels up to the screening limit will not cause the LLW to be hazardous.

This report documents the evaluation to ensure that LLW contaminated with sludge at 10000 $\mathrm{dpm} / 100 \mathrm{~cm}^{2}$ of alpha emitters is nonhazardous. The hazardous constituent present in the greatest ratio to its Resource Conservation and Recovery Act (RCRA) limit is identified, and the concentration of that component in the leachate from a TCLP test is calculated. Finally, implications of this evaluation on screening LLW in the field are identified. 
WSRC-TR-94-0389

Revision 0

Page 3 of 10

\section{SUMMARY}

Solid low level waste that is contaminated with sludge resulting in alpha contamination less than or equal to $10000 \mathrm{dpm} / 100 \mathrm{~cm}^{2}$ is nonhazardous. The waste generated in the F-Area Tank Farm will be 90 times less than the hazardous limit for mercury and waste from the H-Area Tank Farm (except for Tank 11) will be 26 times less than the hazardous limit. Waste generated around Tank 11 will be 6 times below the hazardous limit. Solid LLW generated in the Sludge Processing tanks will be 110 times below the hazardous limit for mercury. These values were calculated using conservative assumptions of maximum mercury and minimum alpha emitter concentrations and the conservative assumption that the contaminated waste was comprised of plastic sheeting only (i.e., the lightest material).

\section{DISCUSSION}

A screening parameter of $10000 \mathrm{dpm} / 100 \mathrm{~cm}^{2}$ of alpha contamination has been implemented as a means to ensure that there is not enough sludge present to cause the LLW to exceed package limits for certain radioisotopes [1]. Significant alpha contamination indicates the presence of sludge, since the principal alpha contributors, plutonium and uranium, are insoluble in alkaline waste solutions [3,4] and accumulate in the sludge. Area smears or smears of actual LLW will be analyzed in the field to determine the gross alpha contamination, and waste from areas exceeding the screening limit will be segregated for additional evaluation by HLWE.

Sludge contamination introduces larger quantities of the TCLP metals (the primary hazardous constituents in HLW) into LLW than does supernate contamination. These metals are also insoluble in caustic solution and become a part of the sludge during the waste generation process within the Canyons. Depending on the concentration of alpha emitters, the quantity of sludge that would contaminate the LLW at the screening limit varies, so the inventory of hazardous components in the waste container could be high enough to cause the waste to be considered hazardous.

To determine if solid LLW is hazardous, a TCLP would ordinarily be performed [5]. A representative sample of the waste is contacted with a specified mass of leach solution ( 20 times the weight of the sample). If the concentration of one or more of the TCLP metals in the leachate is above the RCRA threshold limits, then the waste would be considered hazardous. Due to the practical difficulties in physically obtaining representative samples and performing the procedure with radioactive materials, the concentration in the leachate can alternatively be calculated using the equations developed in Attachment A of Reference [2].

The following evaluation was performed to determine if sludge contamination at levels reflecting $10000 \mathrm{dpm} / 100 \mathrm{~cm}^{2}$ of gross alpha concentration could cause the threshold level for hazardous constituents to be exceeded. The hazardous component present in the greatest ratio to the RCRA limit was identified as the key constituent to be used in the calculations. The quantities of the different sludges (as grouped below) that would result in contamination levels of $10000 \mathrm{dpm} / 100$ $\mathrm{cm}^{2}$ was then calculated based on characterization data for the sludges. Finally, the concentration of the key hazardous component in leachate resulting from a TCLP is evaluated and compared to the RCRA limits. 
WSRC-TR-94-0389

Revision 0

Page 4 of 10

\section{Determination of Key Hazardous Constituent}

The hazardous constituents present in HLW were identified in Reference [2] and were shown to be present in the supernate in extremely low concentrations. The remaining quantity of each of the TCLP metals is in the sludge phase due to the insolubility of the oxides/hydroxides formed in the alkaline solution. Only a few samples have been collected to characterize the sludge due to high radiation exposure, potential for contamination, etc. The more recent samples were specifically chosen to reflect the different types of sludge stored in the Tank Farms from a minimum number of samples. The limited amount of data available for the TCLP metals are presented in Table I.

Mercury is the most plentiful of the TCLP metals, historically having been added in the Separations process at concentrations ranging from $0.002 \mathrm{M}$ to $0.04 \mathrm{M}$ [6]. Sludge generated from PUREX processing in F-Area will typically be lower in $\mathrm{Hg}$ (relative to $\mathrm{H}$-Canyon), since $\mathrm{Hg}$ was only used to catalyze dissolution of Pu-Al targets and scrub alloy scrap. Mercury usage in the H-Canyon facility has been for catalysis of dissolution of stainless steel fuel and Pu-Al targets.

The high concentration of $\mathrm{Hg}$ relative to the other TCLP metals and the relatively low limit in determining hazardous waste result in $\mathrm{Hg}$ being the key hazardous component in the sludge. The RCRA limits for each TCLP metal are shown in Table II. The ratio of the limit for each component and that of $\mathrm{Hg}$ (also shown in Table II) reflect the quantity of each metal relative to $\mathrm{Hg}$ that would have to be present for the RCRA limit to be exceeded for that metal. If the ratios for each metal from sample data (fourth column in Table II) are less than the ratios from the TCLP limits (third column in Table II), then Hg will be the component to cause the RCRA limit to be exceeded. The ratios calculated from the sludge data in Table I were all less than the ratios based on the limits. Therefore, mercury is the key constituent in the sludge.

\section{Evaluation of Mercury Concentration in Leachate}

The gross concentration of alpha emitting radioisotopes in sludge samples is also included in Table I. Because of the scarcity of data and lack of details in preparing some of the earlier samples for analysis, all data were assumed to be for dried sludges. The recent samples provide representative data for the four types of waste sludge (high and low heat wastes from the PUREX and HM processes). Data from multiple samples from the same tank (Tanks 5, 11, 13, 15 and 16) were numerically averaged. Sample data were also combined and averaged to account for sludge removal and transfers of sludge between tanks. A review of the tank histories $[7,8]$ indicates that Tank 13 contains the sludge from Tanks 9,10 and 14 in addition to fresh waste receipts from the Canyon, Tank 15 contains sludge from Canyon waste receipts and sludge from Tank 16, and Tank 42 contains part of the sludge from Tank 15 (used in the Sludge Processing demonstration) and sludge removed from Tank 21. Thus, the values presented in Table III provide an estimate of the $\mathrm{Hg}$ and gross alpha concentrations in the sludge, as currently stored in those tanks. Because the Separations processes that generated the sludges in other tanks have not been significantly altered, the data in Table III provide adequate characterization data for the remaining tanks. (A more detailed characterization of the sludge is outside the scope of this report and will be documented separately.)

\section{E-Area}

The sludge in F-Area tanks was generated solely from PUREX processing in F-Canyon. The primary alpha emitting radioisotope is ${ }^{239} \mathrm{Pu}$. The concentration of gross alpha in the sludge ranges from 0.06 to $0.4 \mathrm{mCi} / \mathrm{gm}$, and the mercury concentration ranges from 0.06 to $0.65 \mathrm{wt} \%$. 
WSRC-TR-94-0389

Revision 0

Page 5 of 10

At the conservative extreme of high mercury and low alpha content, the amount of sludge that would produce gross alpha contamination of $10000 \mathrm{dpm} / 100 \mathrm{~cm}^{2}$ was calculated to be 0.075 $\mathrm{mg} / 100 \mathrm{~cm}^{2}$.

The low level waste that would be sludge contaminated was conservatively assumed to be only comprised of 6 mil plastic sheeting. Plastic sheeting is commonly used within the Tank Farms for contamination control and is one of the lightest materials used (the density is $0.8 \mathrm{gm} / \mathrm{cm}^{3}$ ). Since the amount of leachate used in the TCLP depends on the weight of the representative sample, assuming contamination of only the lightest material will result in the maximum mercury concentration in the leachate. However, not all of the plastic will be contaminated, and recent studies indicate that only $3 \%$ of the material is contaminated [9]. For this study, contamination is conservatively assumed to be present on $10 \%$ of the plastic. The concentration of $\mathrm{Hg}$ in the leachate is calculated to be $0.0021 \mathrm{mg} /$, which is 90 times less than the TCLP limit of $0.2 \mathrm{mg} /$.

\section{H-Area}

Sludges in H-Area tanks are either a combination of PUREX and HM wastes (due to the PUREX processing initially performed in H-Canyon) or solely $\mathrm{HM}$ waste. The alpha contamination is mainly due to isotopes of $\mathrm{Pu}$, which are considered undesired byproducts in fuel reprocessing. The gross alpha concentrations ranged from approximately 0.02 to $0.7 \mathrm{mCi} / \mathrm{gm}$. For H-Area sludge, $0.19 \mathrm{mg} / 100 \mathrm{~cm}^{2}$ of sludge would result in $10000 \mathrm{dpm} / 100 \mathrm{~cm}^{2}$, conservatively assuming that mercury is present at the highest concentration in Table III, and gross alpha is at the lowest concentration. If the low alpha sludge present in Tank 11 is excluded from the analysis, only $0.069 \mathrm{mg} / 100 \mathrm{~cm}^{2}$ is necessary to reach the screening limit.

The low level waste was, as before, assumed to consist only of plastic sheeting. The mercury concentration in the leachate was calculated to be $0.032 \mathrm{mg} /$ for the H-Area sludge. It is interesting to note that the leachate from the Tank 11 sludge by itself results in the same mercury concentration, due to the assumption of the high $\mathrm{Hg}$ content of the sludge. Excluding Tank 11 sludge from the remaining $\mathrm{H}$-Area sludges decreases the $\mathrm{Hg}$ concentration in the leachate to 0.0078 $\mathrm{mg} /, 26$ times less than the TCLP limit.

\section{Sludge Processing}

Sludge in Tanks 42 and 51 is a mixture of PUREX and HM sludges, and have been partially prepared (aluminum dissolution and some washing) as feed to the DWPF. For the minimum alpha content of $0.065 \mathrm{mCi} / \mathrm{gm}$ and the maximum $\mathrm{Hg}$ content of $0.6 \mathrm{wt} \%$, the waste would have to be contaminated with sludge at a level of $0.069 \mathrm{mg} / 100 \mathrm{~cm}^{2}$. This would result in a mercury concentration in the leachate of $0.0018 \mathrm{mg} /$.

\section{Average Sludge}

To represent the overall LLW stream from the entire Tank Farms, the average sludge composition was calculated. The alpha limit of $10000 \mathrm{dpm} / 100 \mathrm{~cm}^{2}$ would require contamination with 0.024 $\mathrm{mg} / 100 \mathrm{~cm}^{2}$ sludge. The mercury concentration in the leachate would be $0.0015 \mathrm{mg} /$, approximately 140 times less than the TCLP limit. It is important to note that this value was calculated from the average sludge concentrations, whereas calculations for the individual sludge groupings above were performed using maximum $\mathrm{Hg}$ and minimum alpha (i.e., extreme) concentrations. 
WSRC-TR-94-0389

Revision 0

Page 6 of 10

\section{Implications for LLW Generation}

The results of the calculations are summarized in Table IV.

Solid low level waste generated in the Tank Farms that is contaminated with less than 10000 $\mathrm{dpm} / 100 \mathrm{~cm}^{2}$ of alpha material is nonhazardous. Thus, all supernate contaminated LLW will satisfy the EAV Acceptance Requirements that the waste be nonhazardous. By applying the screening limit for sludge contamination and assuming the most conservative values of mercury and alpha composition, the LLW stream contaminated with HLW supernate will be between 6 and 110 times below the hazardous limit. For the overall LLW stream from the Tank Farms, the waste would be approximately 140 times below the hazardous limit.

Alternatively presented, LLW from the F-Area Tank Farm could be contaminated with enough sludge to result in an alpha contamination of $900000 \mathrm{dpm} / 100 \mathrm{~cm}^{2}$ before the waste would require segregation for more detailed evaluation of hazardous components. Waste generated in the H-Area Tank Farm (except for Tank 11) could be contaminated with approximately $260000 \mathrm{dpm} / 100 \mathrm{~cm}^{2}$ of alpha emitters before the waste would require segregation. Low level waste generated in the Sludge Processing Tanks could be contaminated with enough sludge to generate an alpha contamination of over 1 million $\mathrm{dpm} / 100 \mathrm{~cm} 2$. The most restrictive situation is for Tank 11 , whose waste would be only 6 times below the hazardous limit.

Therefore, the $10000 \mathrm{dpm} / 100 \mathrm{~cm}^{2}$ alpha contamination screening limit can be confidently applied to ensure that the characterization for supernate contaminated LLW is valid.

\section{ACTIONS}

NONE

\section{REEERENCES}

[1] M. E. Jamison, P. D. d'Entremont, J. S. Clemmons, C. E. Bess and D. F. Brown, "High Level Waste Characterization in Support of Low Level Waste Certification (U) I. HLW Supernate Radionuclide Characterization", WSRC-TR-94-0290, July 8, 1994.

[2] G. K. Georgeton, "Characterization of Hazardous Constituents in HLW Supernate and Implications for Solid LLW Generation (U)", WSRC-TR-94-0297, June 22, 1994.

[3] D. T. Hobbs, T. B. Edwards and S. D. Fleischman, "Solubility of Plutonium and Uranium in Alkaline Salt Solutions (U)", WSRC-TR-93-056, February 12, 1993.

[4] D. T. Hobbs and T. B. Edwards, "Solubility of Plutonium in Alkaline Salt Solutions (U)", WSRC-TR-93-131, February 26, 1993.

[5] South Carolina Hazardous Waste Management Regulations, R.61-79.261, Appendix II, Method 1311 Toxicity Characteristic Leach Procedure (TCLP).

[6] C. E. Pickett, T. G. Campbell and W. E. Harris, "Mercury Requirement for Separations Processes", OPS-STH-89-0145, November 27, 1989. 
WSRC-TR-94-0389

Revision 0

Page 7 of 10

[7] W. S. Cavin and A. T. Crumm, "Fresh Waste Receipts (U)", WSRC-TR-93-426, Rev 1, January 21, 1994.

[8] W. S. Cavin and A. T. Crumm, "Waste Transfers and Miscellaneous Additions (U)", WSRC-TR-93-425, Rev 1, January 21, 1994.

[9] R. S. Thomason, "Radioisotope Characterization of FB-Line Low-Activity Waste (U)", WSRC-TR-94-0288, June 20, 1994, DRAFT.

[10] J. A. Stone, "Separation of SRP Waste Sludge and Supernate", DP-1441, November 1976.

[11] J. A. Stone, J. A. Kelley and T. S. McMillan, "Sampling and Analyses of SRP High-Level Waste Sludges", DP-1399, August 1976.

[12] J. R. Fowler, "Chemical and Radiochemical Analyses of SRP Liquid Waste", DPST-80-409, May 1981.

[13] T. L. Davis, D. W. Tharin and D. R. Lohr, "History of Waste Tank 11, 1955 Through 1974", DPSPU-78-11-12, October 1978.

[14] T. L. Davis, D. W. Tharin, D. W. Jones and D. R. Lohr, "History of Waste Tank 14, 1957 through 1974", DPSPU-77-11-19, August 1977.

[15] G. B. Woolsey, R. M. Galloway, M. J. Plodinec, E. L. Wilhite and J. R. Fowler, "Processing of Tank 15 Sludge", DPST-80-361, June 30, 1980.

[16] J. A. Stone, "Detailed Analyses of SRP High-Level Waste Sludges", DPST-76-425, October 6, 1976.

[17] W. L. Poe, "Leakage From Waste Tank 16 - Amount, Fate, and Impact", DP-1358, November 1974.

[18] F. G. McNatt, "History of Waste Tank 21, 1961 Through 1974", DPSPU-78-11-10, October 1978.

[19] N. E. Bibler, S. B. Wyrick, M. S. Hay and C. J. Coleman, "Preliminary Measurements of Nonradioactive Components in Tank 42 Sludge-Slurry Using ICP-MS (U)", SRT-GTC-92-0040, November 23, 1992.

[20] C. J. Coleman, N. E. Bibler and R. A. Dewberry, "Analyses of High Level Radioactive Glasses and Sludges at the Savannah River Site", Proceedings of the Symposium on Waste Management, pg 652-657, Tucson, AZ, February 1990. 
Table I. HLW Sludge Sample Data

\begin{tabular}{|c|c|c|c|c|c|c|c|c|c|c|c|}
\hline \multirow[b]{2}{*}{ Tank } & \multirow{2}{*}{$\begin{array}{c}\text { Sample } \\
\text { Date } \\
\end{array}$} & \multicolumn{8}{|c|}{ Concentration in Sludge (wt\%) } & \multirow{2}{*}{$\begin{array}{c}\text { Gross alpha } \\
\text { (mCi/gm) }\end{array}$} & \multirow[b]{2}{*}{ Reference } \\
\hline & & $\mathbf{A g}_{\mathbf{g}}$ & As & $\overline{\mathbf{B a}}$ & $\mathbf{C d}$ & $\mathbf{C r}$ & $\mathrm{Hg}$ & $\mathrm{Pb}$ & Se & & \\
\hline $4,6 \mathrm{camb}$ & 1976 & & & & & & 0.65 & & & 0.4 & [10] \\
\hline 5 & 1976 & & & & & & 0.12 & & & 0.1 & [10] \\
\hline 5 & Oct-74 & 0.04 & & 0.25 & & 0.3 & 0.1 & 0.04 & & 0.1 & [11] \\
\hline 7 & Sep-74 & 0.3 & & 0.13 & $<0.05$ & 0.45 & 0.06 & 0.25 & & 0.06 & [11] \\
\hline 9 & Jul-66 & $<0.1$ & & $0.1-0.5$ & & 0.5 & & 0.7 & & 0.0026 & [12] \\
\hline 10 & Feb-67 & & & $<0.1$ & & 0.4 & & & & 0.0047 & [12] \\
\hline 11 & Dec-69 & & & & & & & & & 0.0460 & [13] \\
\hline 11 & Jun-58 & & & & & & & & & 0.0010 & [13] \\
\hline 12 & Sep-75 & & & & & & 1.1 & & & 0.7 & {$[10,12]$} \\
\hline 13 & 1976 & & & & & & 2.32 & & & 0.2 & {$[10]$} \\
\hline 13 & Aug-74 & $<0.1$ & & 0.15 & & 0.09 & 2.1 & 0.5 & & 0.28 & [11] \\
\hline 14 & Feb-60 & & & & & & & & & 0.002 & {$[12,14]$} \\
\hline 15 & Apr-79 & $<0.1$ & & $0.1-0.5$ & & 0.3 & 9.4 & & & & {$[12,15]$} \\
\hline 15 & Aug-75 & & & & & & 2.6 & & & 0.1 & {$[10,12]$} \\
\hline 15 & Oct-74 & & & $0.1-0.5$ & & $<0.1$ & 0.9 & & & 0.14 & {$[10,11,12,16]$} \\
\hline 16 & 1976 & & & & & & 2.8 & & & 0.15 & [10] \\
\hline 16 & May-60 & & & & & & & & & 0.0150 & [17] \\
\hline 21 & Jen-70 & & & & & & & & & $1.1 \mathrm{E}-05$ & [18] \\
\hline 42 & Oct-92 & & & & & 0.1 & 0.6 & & & & [19] \\
\hline 51 & 1991 & & & & & 0.21 & 0.023 & & & 0.107 & [20] \\
\hline
\end{tabular}


WSRC-TR-94-0389

Revision 0

Page 9 of 10

Table II. Relative Concentrations of Hazardous Constituents to Mercury

\begin{tabular}{|c|c|c|c|}
\hline \multirow[b]{2}{*}{ Component } & TCLP & \multicolumn{2}{|c|}{ Ratio to $\mathrm{Hg}$ Concentration } \\
\hline & $\begin{array}{l}\text { Limit } \\
(\mathrm{mg} / \mathrm{f})\end{array}$ & $\begin{array}{l}\text { TCLP } \\
\text { Value }\end{array}$ & $\begin{array}{l}\text { Maximum } \\
\text { Sample }\end{array}$ \\
\hline$\overline{\mathrm{Ag}}$ & 5 & 25 & 5 \\
\hline As & 5 & 25 & No data \\
\hline $\mathrm{Ba}$ & 100 & 500 & 2.5 \\
\hline $\mathrm{Cd}$ & 1 & 5 & 0.83 \\
\hline $\mathrm{Cr}$ & 5 & 25 & 9.1 \\
\hline $\mathrm{Hg}$ & 0.2 & 1 & 1.0 \\
\hline $\mathrm{Pb}$ & 5 & 25 & 4.2 \\
\hline $\mathrm{Se}$ & 1 & 5 & No data \\
\hline
\end{tabular}

Table III. Mercury and Alpha Characterization of HLW Sludges

\begin{tabular}{|c|c|c|}
\hline Tank & $\begin{array}{c}\mathrm{Hg} \text { Conc'n } \\
(w \mathrm{t} \%)\end{array}$ & $\begin{array}{c}\text { alpha } \\
\text { (mCi/gm) }\end{array}$ \\
\hline $4,6 \mathrm{comb}$ & 0.65 & 0.4 \\
\hline 5 Avg. & 0.11 & 0.1 \\
\hline 7 & 0.06 & 0.06 \\
\hline 11 Avg. & $3.9 *$ & 0.024 \\
\hline 12 & 1.1 & 0.7 \\
\hline 13 Avg. & 2.2 & 0.098 \\
\hline 15 Avg. & 3.9 & 0.13 \\
\hline 42 & 0.6 & 0.065 \\
\hline 51 & 0.023 & 0.107 \\
\hline
\end{tabular}

* Tank $11 \mathrm{Hg}$ concentration assumed to be the same as for Tank 15. Tank 11 contained mostly HM-HHW, similar to Tank 15. 
WSRC-TR-94-0389

Revision 0

Page 10 of 10

Table IV. Mercury Concentration in the Leachate for Solid LLW

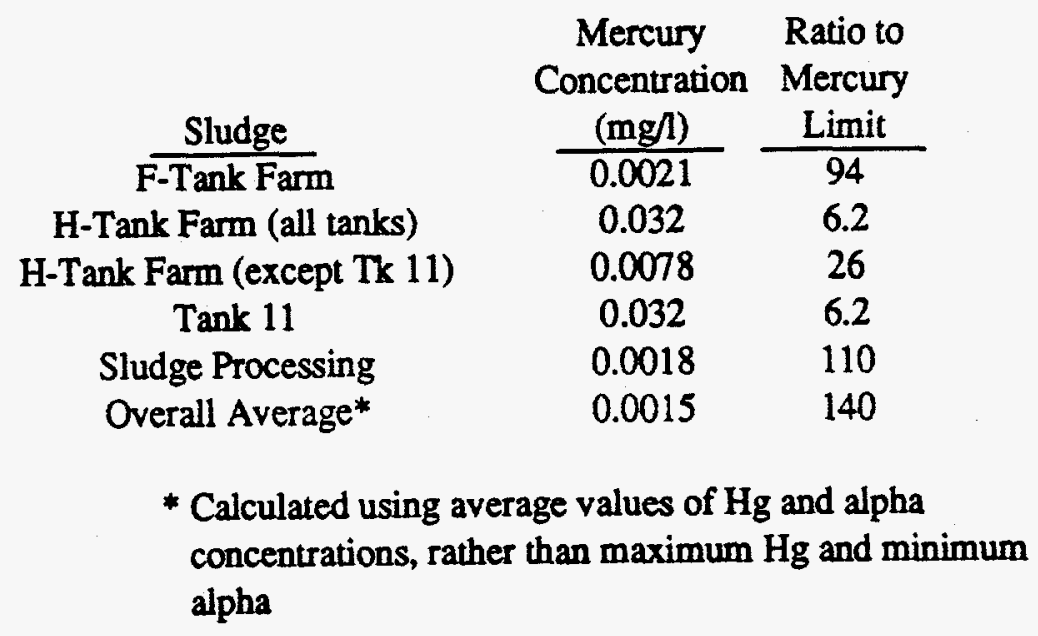

